\title{
CHANGING ATTITUDES THROUGH INTERNATIONAL PARTICIPATION: EUROPEAN PARLIAMENTARIANS AND INTEGRATION
}

Henry H. Kerr, Jr.

\begin{abstract}
Regional integration theory emphasizes elite social learning and attitude change as concomitant processes of integration. Participation by national elites in EEC decision making may bring about these changes. To test these hypotheses, French and German delegates to the European Parliament were interviewed, and their attitudes compared with those of a control group sampled among their national colleagues. The general finding was that the delegates' attitudes appear to undergo cognitive, but not affective, changes. Delegates develop more complex perceptions and become better informed and more interested in European matters, yet they become neither more favorable nor less hostile to these issues because of the self-recruitment of many legislators who were avowed Europeans before their nomination. Strong ties to national parties apparently diminish the attitudinal effects of this learning experience. Only when the parliament has full time legislators who exercise potent policy-making tasks will its role in European integration increase.
\end{abstract}

\section{REGIONAL INTEGRATION AND SOCIAL LEARNING}

Of the many ventures in regional economic cooperation, the European Economic Community (EEC) and its forerunner, the European Coal and Steel Community (ECSC), stimulated a particularly strong concern with the construction of theories of regional integration. These two organizations have provided, in effect, a living laboratory to test hypotheses about the processes of economic and political integration. In the supranational character of the community institutions, some observers have seen the seeds of a federation of European states. ${ }^{1}$ In

Henry H. Kerr, Jr., is a member of the Department of Political Science of the University of Geneva in Switzerland.

${ }^{1}$ This is a theme that runs through much of the early literature on European integration written by European scholars. See, for example, Dusan Sidjanski, "Aspects fédératifs de la Communauté Européenne," paper presented before the Sixth World Congress of Political Science, Geneva, 21-25 September 1964. 
the increase in the flow of persons and goods across national borders, sources of heightened interdependence among the member states have been identified. ${ }^{2}$ In the cooperation of national interest groups at the community level, forces serving to increase demands for expansion of the scope of the community's activities have also been isolated. ${ }^{3}$ The common concern, in all these theoretical efforts, has been at once to define and to measure political community formation. ${ }^{4}$

Central to this theoretical work is the notion that integration implies changes in the attitudes and expectations of the participants in the direction of an increased commitment to regional cooperation. It was the vitality of transnational group activities in the early days of the ECSC that, in part, led Haas to define political integration in precisely these same terms, namely as

... the process whereby political actors in several distinct national settings are persuaded to shift their loyalties, expectations, and political activities to a new center, whose institutions possess or demand jurisdiction over the pre-existing national states. ${ }^{5}$

In a similar vein, Deutsch has argued that one of the preconditions for political unification is the emergence of a sense of community-of reciprocal identification and loyalties-among the participant members, ${ }^{6}$ while Etzioni has placed particular stress on what he calls the "identitive" power of regional organizations to mobilize the loyalties of member populations in support of new institutions. ${ }^{7}$

Underlying the literature on European integration are hypotheses such as these that view it as a social-psychological process of attitude

\footnotetext{
'See, for example, Hayward Alker, Jr., and Donald Puchala, "Trends in Economic Partnership: The North Atlantic Area, 1928-1963," in J. David Singer (ed.), Quantitative International Politics: Insights and Evidence (New York: The Free Press, 1968), pp. 287-316.

'For the two leading exponents of this approach, see Ernst B. Haas, The Uniting of Europe: Political, Social, and Economic Forces, 1950-1957 (Stanford: Stanford University Press, 1958), and Leon N. Lindberg, The Political Dynamics of European Economic Integration (Stanford: Stanford University Press, 1963). For an extension of this kind of argument to relations among nations in general, see Robert C. Angell, Peace on the March: Transnational Participation (New York: van Nostrand Rheinhold, 1969).

- For recent discussions of problems in operational definitions and measurement of regional integration, see Joseph S. Nye, "Comparative Regional Organization: Concept and Measurement," International Organization, Autumn 1968 (Vol. XXII, No. 4), pp. 855-880, and Leon N. Lindberg and Stuart A. Scheingold, Regional Integration: Theoretical Research (Cambridge: Harvard University Press, 1971), pp. 45-127.

'Haas, The Uniting of Europe, p. 16.

- Karl W. Deutsch et al., Political Community and the North Atlantic Area: International Organization in the Light of Historical Experience (Princeton: Princeton University Press, 1959).

'Amitai Etzioni, Political Unification: A Comparative Study of Leaders and Forces (New York: Holt, Rinehart, and Winston, 1965), pp. 16-34.
} 
change ${ }^{8}$ or of international social learning. ${ }^{9}$ These hypotheses are based on the proposition that as community decisions tend to stimulate more contact among the elites and citizens of the member states, and as more and more people come to participate directly in these decisions and to perceive them as mutually rewarding, these people will develop more favorable attitudes toward integration..$^{10}$ It is further argued that these changes in attitudes diffuse in ever widening circles from the elites, who are directly involved in the decisions and activities of the fledging central authority, to the mass publics who later receive the cues and messages addressed to them by their national elites. ${ }^{11}$ This process of diffusion of attitude change may thus complement and even stimulate the "spill-over" of functional activity from one sectorial area of cooperation to another.

These hypotheses are taken as articles of faith, for little systematic research has been conducted to test them. The European Community provides, in fact, many institutional settings where the continuous contact among public officials and private citizens may well facilitate processes of social learning. National ministers of the six member states have spent long hours in consultations at the negotiating table in the Council of Ministers at Brussels. Hundreds of civil servants, technical experts, and unofficial advisers have met with one another to hammer out agreements in the Committee of Permanent Representatives. A host of national interest groups, voluntary organizations, and other non-governmental associations have organized at the community level and are encouraged by the commission to participate in informal discussions with community officials. ${ }^{12}$ In plenary and committee sessions of the European Parliament at Strasbourg, legislators recruited from the national parliaments of the member states meet to debate the decisions of the community and to exercise its power of "deliberation and control." Finally, as barriers to the free movement of labor and persons have been reduced, tourism, student exchange, and migration have increased. ${ }^{13}$

- Herbert C. Kelman suggested this formulation in a seminar at the University of Michigan in the fall of 1965.

-Donald J. Puchala, "The Pattern of Contemporary Regional Integration," International Studies Quarterly, March 1968 (Vol. XII, No. 1), pp. 51-55.

${ }^{20}$ Herbert C. Kelman (ed.), International Behavior: A Social-Psychological Analysis (New York: Holt, Rinehart, and Winston, 1965), p. 573.

"See Ronald Inglehart, "Public Opinion and Regional Integration," International Organization, Autumn 1970 (Vol. XXIV, No. 4), pp. 764-795.

"See, for example, the work of Jean Meynaud and Dusan Sidjanski, L'Europe des Affaires: Rôle et Structure des Groupes (Paris: Payot, 1967), and Les Groupes de pression dans la Communauté Europjéenne (Brussels: Institut de Sociologie, Université Libre de Bruxelles, 1971).

${ }^{13}$ See Donald J. Puchala, European Political Integration: Progress and Prospects, Appendix 6, Arms Control in the European Political Environment, (New Haven: Political Science Research Library, Yale University, January, 1966), pp. 68-69. 
Yet it is not known if this increase in personal contact and participation in community activities has resulted in a heightened commitment to integration, for little empirical research has been conducted on the effects of crossnational contact in the European setting, especially among national elites. ${ }^{14}$

Since the participation of many national elites in nearly all phases of decision making in the EEC is viewed as one of its distinctive features,,$^{15}$ the absence of empirical findings on the effects associated with this participation is a notable lacuna in the accumulation of systematic knowledge about the process of integration. ${ }^{16}$ If this process is equated, as Haas postulated, with changes in the attitudes, expectations, and activities of political actors in the national settings, their active involvement in the affairs of the European Community may constitute one source of attitude change. As Haas himself has observed, the question is: "do people 'learn' to think in non-national terms because of a pattern of ... cooperation?" Since "this is indeed the central issue in the Functionalist theory of change,"17 it deserves careful empirical examination.

\section{PARTICIPATION IN THE EUROPEAN PARLIAMENT AS A LEARNING EXPERIENCE}

The European Community provides numerous institutional settings for regular contact among national elites whose participation in joint activities may not only be mutually rewarding but may also involve a

\footnotetext{
${ }^{14}$ The few published works usually have to do with the effects of travel on attitudes toward European questions. See, for example, Nels Anderson and Erich Reigrotski, "National Stereotypes and Foreign Contacts," Public Opinion Quarterly, 1959 (Vol. XXIII, No. 4), pp. 515-529. There are, of course, several studies on elite attitudes toward European integration, but none of them explicitly investigated the impact of participation in international activities. Among the more notable studies of elite attitudes per se are Karl Deutsch et al., France, Germany and the Western Alliances: A study of Elite Attitudes on European Integration and World Politics (New York: Charles Scribner's Sons, 1967); Karl Deutsch, Arms Control and the Atlantic Alliance: Europe Faces Coming Policy Decisions (New York: John Wiley and Sons, 1967) ; and, Daniel Lerner and Morten Gorden, Euratlantica: Changing Perspectives of the European Elites (Cambridge, Mass.: M.I.T. Press, 1969). The sole study I know of that deals directly with the attitudinal effects of international participation is Bonham's research on Scandinavian legislators: G. Matthew Bonham, "Participation in Regional Parliamentary Assemblies: Effects on Attitudes of Scandinavian Parliamentarians," Journal of Common Market Studies, June 1970 (Vol. VIII, No. 4), pp. 325-336.

${ }^{15}$ Lindberg, The Political Dynamics of European Economic Integration, passim.

${ }^{18}$ See Ernst B. Haas, "The Study of Regional Integration: Reflections on the Joy and Anguish of Pretheorizing," International Organization. Autumn 1970 (Vol. XXIV, No. 4), p. 643.

${ }^{17}$ Haas, Beyond the Nation-State: Functionalism and International Organization (Stanford: Stanford University Press, 1964), p. 13.
} 
common learning experience. Among these institutions is the European Parliament. Located in Strasbourg, it is the site of intense interaction among 142 legislators chosen from the ranks of the six national parliaments. It provides participants with an international parliamentary forum to discuss the issues confronting the community and a stimulus to acquire new habits and attitudes about international cooperation in general, and European integration in particular.

As a deliberative body, the European Parliament is nontheless severely limited in its powers to make authoritative decisions. Its recommendations may or may not be heeded by the commission or the Council of Ministers. Measures proposed by its members may or may not be adopted by the national parliaments or governments of the member states. In many instances, of course, their opinions or their questions may carry weight in decision-making processes by virtue of expert argument. Yet though the powers conferred upon the parliament by the Treaty of Rome place it a rung above the other European consultative assemblies, ${ }^{18}$ the measurable influence of these instance is minimal. ${ }^{19}$ In short, the European Parliament is seen to play a negligible role in the decisions that have shaped the rate and direction of integration within the EEC. ${ }^{20}$

The experiences that participation in its activities affords the member delegates may, however, alter their cognitions, attitudes, and behavior. As Lindberg has argued, one of the principal functions of the parliament may be to change "the attitudes, the expectations, and the focus of more and more people."21 One may expect, in particular, that the more rewarding this experience is for the participants, the more likely it is that they will develop broader perspectives and come to hold more positive attitudes toward regional integration. ${ }^{22}$ Moreover, the members may become avowed advocates of integration in their respective national parliaments. Not only may they try to persuade their na-

\footnotetext{
${ }^{18}$ Henri Manzanarés, Le Parlement Européen (Paris: Editions Berger-Levrault, 1964), and Eric Stein, "The European Parliamentary Assembly: Emerging Techniques of 'Political Control',' International Organization, Spring 1959 (Vol. XIII, No. 2), pp. 233-254. For a comparative study of international parliamentary assemblies in Western Europe, see Kenneth Lindsay (ed.), European Assemblies: The Experimental Period, 1949-1959 (New York: Frederick A. Praeger, 1960).

${ }^{19}$ One investigator devoted an entire manuscript to validate this thesis. See John E. Schwarz, "Power, Persuasion, and the Influence of the European Parliament," (unpublished Ph.D. dissertation, Indiana University, 1967).

${ }^{20}$ Leon N. Lindberg, "The Role of the European Parliament in an Emerging European Community," in Elke Frank (ed.), Lawyers in a Changing World (Englewood Cliffs, N. J.: Prentice-Hall, 1966), pp. 101-128.

${ }^{11}$ Ibid, p. 120.

" For a general statement of these hypotheses, see Herbert C. Kelman, "Changing Attitudes through International Activities," Journal of Social Issues, 1962 (Vol. XVIII, No. 1), pp. 67-87.
} 
tional colleagues to support measures that further the goal of integration, but these colleagues in the home parliaments may also come to value their opinions for the expertise acquired by working in the parliament. Seen in this light, the contribution of the European Parliament to integration within the EEC ought to be judged, perhaps, not so much for the role it plays in community decisions, but rather as a vehicle which serves to stimulate a joint learning process among legislative elites of the member countries. As Claude observed,

... the extraordinary significance of the institutional developments within the European Community is not limited to the invention of supranationality. These institutions have infranational aspects, in that they impinge directly upon individuals and associations within the member states and, particularly in the Assembly [i.e., the European Parliament], involve official participation of individuals who speak from a lower level than that of national government.... The fact that they set officials above the state level may be no more important than that they reach below the state level and encourage affiliation across the plane of state boundaries. ${ }^{23}$

What aspects of the experience an individual member obtains through this participation may be adduced to suggest that a learning process is at work? What are the factors which may contribute to changes in his perceptions and attitudes? What kinds of effects may one expect to observe? Research on the parliament and on the effects of participation in similar international activities points to a study of changes in the cognitive and affective components of a member's attitudes ${ }^{24}$ and suggests several factors which may bring them about: (1) exposure to new information, (2) continuous contact with foreign colleagues, (3) assumption of non-national roles, and (4) exposure to group norms and pressures.

As a first hypothesis, one might expect that as members of the parliament are exposed to a welter of new and often challenging information within the assembly, they may broaden their outlook on integration, appreciate more easily the complexity of the issues, and entertain and tolerate opposing views more readily. In short, their cognitions of European integration may become more complex and differentiated as a result of this experience. This is, in fact, a major finding of social scientists studying participation in smiliar international activities. Alger, for instance, interviewed a sample of 25 first term representatives to

\footnotetext{
Inis L. Claude, Jr., Swords into Plowshares: The Problems of International Organization, 3rd Ed. (New York: Random House, 1964), pp. 104-105, italics in the original.

"See William A. Scott, "Psychological and Social Correlates of International Images," in Kelman (ed.), International Behavior, p. 72.
} 
the United Nations General Assembly before they assumed their posts and again at the end of their first session three months later. He found that these delegates were much more aware of the issues, were less prone to perceive them in black and white terms, and had become more skilled in parliamentary diplomacy. ${ }^{25}$ Fens observed that delegates to the assembly of the Western European Union developed a broader awareness of defense problems faced by other member countries and "learnt to look at the problem in a genuine Western perspective."26 Haas found these effects more specific in character; members of the ECSC Common Assembly developed broader perspectives, outgrowing "the boundaries of the national state as the referents of legislative action." ${ }^{27}$ Lastly, in a comparative study of European parliamentary assemblies, Lindsay came to a similar conclusion. In his opinion, "there is no doubt that the experience of working in European assemblies has enlarged the outlook of individual members ..."28

The continual face-to-face contact among the delegates is another form of perceptual information acquired by participation in the parliament. In general, the effects of close collaboration in this arena may be similar to those of cultural exchange programs in which "the contact will provide richer and more accurate information about other people and will show them to be much like members of one's own group."28 Also, since the members devote the bulk of their legislative activity to committee work and choose committee assignments in function of specific policy interests, they are frequently in situations where the sharing of similar professional concerns is very salient. It is especially in committee meetings that members have

... the opportunity of coming together with people who share specific tasks, professions, and interests. These shared tasks [thus] could form the basis of continuing relations that are extranational in content and perhaps supranational in commitment. ${ }^{30}$

` Chadwick F. Alger, "United Nations Participation as a Learning Experience," Public Opinion Quarterly, Fall 1963 (Vol. XXVII, No. 3), pp. 425-426. For a broad summary of his research on the effects of personal contact in the United Nations, see Alger, "Personal Contact in Intergovernmental Organizations," in Kelman (ed.), International Behavior, pp. 523-547.

${ }^{\text {s }}$ Colonel J. J. Fens, The Future of Western Defence on the Executive and Parliamentary Levels, Western European Union, Committee on Defence Questions and Armaments, Document 231, May 3, 1962, p. 29, cited in J. Allan Hovet, Jr., The Super-Parliaments: Inter-Parliamentary Consultation and Atlantic Cooperation (New York: Frederick A. Praeger, 1966), p. 81.

${ }^{27}$ Haas, The Uniting of Europe, p. 438.

${ }^{*}$ Lindsay, European Assemblies, p. 94.

- Daniel Katz, "The Functional Approach to the Study of Attitudes," Public Opinion Quarterly, Summer 1960 (Vol. XXIV, No. 2), p. 193.

"Anita L. Mishler, "Personal Contact in International Exchanges," in Kelman (ed.), International Behavior, p. 522. 
Members of the European Parliament are also frequently called upon to assume a variety of non-national roles. ${ }^{31}$ Membership itself is a non-national role in that the legislative mandate of the parliament involves continuous review of the combined activities of the commission and the Council of Ministers. Beyond the simple act of membership, a newly recruited delegate is quickly inducted into more clearly defined roles. Most important is that, with the exception of the Gaullists, nearly all delegates are members of one of the three cross-national political groups organized under the parliament's rules of procedure.$^{32}$ It is the political groups, not the national delegations, which structure the delegates' experiences and activities within the parliament. ${ }^{33}$ The delegates may also serve as committee rapporteurs whose duty it is to prepare a committee report and to defend it before the parliament, as group spokesmen for the collective position of a political group in plenary sessions, or as elected or appointed officials who insure the orderly conduct of the parliament's business. In all these roles, a member may often be expected to defend positions discrepant from his own.

The political groups especially tend to exert strong pressures on their members to reach intra-group compromises on issues during presession caucuses and to allow spokesmen to present the group positions in plenary debates. ${ }^{34}$ Members consequently show a marked aversion to the expression of purely national points of view. What Kapteyn said of the ECSC's Common Assembly still holds today for the European Parliament:

Obviously, this tendency did not mean that national considerations no longer played a part in the forming of opinions. It is

a The term "non-national role" is taken from Alger's insightful discussion of the learning experiences associated with participation in the UN General Assembly. See Alger, in ibid, pp. 532-540.

Article 36 of the Rules of Procedure. The political groups organized under this rule are the Christian Democrats, the Socialists, the Liberals, and the European Democratic Union (UDE), which is composed solely of French Gaullists. The number of non-inscrits, those members who belong to no political group, is very small. In January, 1969, the Italian Communist Party (PCI) was finally allowed to send representatives to the European Parliament; these delegates are among the handful of non-inscrits.

"Committee assignments are made on the basis of a "fair representation" of the political groups; nominations for election to the parliament's elected offices are made by the political groups; the order of speakers in plenary sessions gives priority to group spokesmen-in short, the four political groups are instrumental in determining the roles that delegates may play in the parliament. See Murray Forsyth, The Parliament of the European Communities (London: Political and Economic Planning, March 9, 1964), pp. 27-37, and Guy Van Oudenhove, The Political Parties in the European Parliament: The First Ten Years (September, 1952-September, 1962) (Leyden: A. W. Sijthoff, 1965), pp. 139-148.

"Lindberg, in Frank (ed.), Lawyers in a Changing World, p. 116, and Gerda Zellentin, "Form and Function of the Opposition in the European Communities," Government and Opposition, April-July 1967 (Vol. II, No. 3), p. 420. 
not surprising, therefore, that each national group had certain favourite questions which the members repeatedly brought before the Assembly. Not only national, but also some regional and party interests were advocated. It is a sign of the atmosphere prevailing, however, that the delegates often apologized for doing so. The reaction of group colleagues was quick to follow if one of their members went too far. ${ }^{35}$

Thus, for a member of a political group to obtain the group's approval of a personal resolution, he must be prepared to bend his own views to what he perceives as the group's consensus on the issue. For a committee rapporteur or a group spokesman to continue to enjoy the confidence of fellow colleagues in his ability to represent them, he may well have to take a position in accord with their expectations rather than his own preferences. To the degree that these roles do oblige the incumbents to make statements and to take actions that are discrepant from their own attitudes, the taking of these roles may influence their attitudes, probably in the direction of the perceived norm of the group. ${ }^{36}$

The European Parliament appears, in fact, to be infused by a strong current of pro-European sentiment. It is, on balance, recognized as the most pro-European of the European Community's three institutions. The resolution and recommendations prepared by its political groups and committees frequently take positions that exceed, in large measure, the positions taken in regulations drafted by the commission or in decisions adopted by the Council of Ministers. ${ }^{37}$ On the issue of political unification, the parliament has, for example, been adamant and almost unanimous in supporting measures that would promote some

\footnotetext{
${ }^{25}$ P. J. G. Kapteyn, "The Common Assembly of the European Coal and Steel Community," in Lindsay (ed.), European Assemblies, p. 241. Also see Van Oudenhove, The Political Parties in the European Parliament. pp. 49-50.

This formulation is taken from social psychological studies of the effects of role playing on attitudes. The general finding is that "public expressions of opinion tend to represent some compromise between the individual's 'real' attitude and that which he perceives to be the dominant attitude or norm of the group. Although it is easy to think of these public expression as superficial and 'expedient,' they may have some of the real attitudinal effects of role-playing, for the individual is indeed constrained to play a role located somewhere between his own position and that of the group. If this is so, then repeated role playings vis-à-vis a given group would lead us to expect a slow but real drift in underlying attitude toward the norm group over time." Theodore M. Newcomb, Ralph H. Turner, and Philip E. Converse, Social-Psychology: The Study of Human Interaction (New York: Holt, Rinehart, and Winston, 1965), pp. 108-109. For a review of the literature on the effects of role playing and its relevance to altering the attitudes of elites toward one another, see Milton J. Rosenberg, "Attitude Change and Foreign Policy in the Cold War Era," in James N. Rosenau (ed.), Domestic Sources of Foreign Policy (New York: The Free Press, 1967), pp. 138-139.

${ }^{\text {s7 }}$ See, for example, Lindberg, The Political Dynamics of European Economic Integration, pp. 86-91.
} 
form of political federation among the six member states. ${ }^{38}$ Jealous of the legislative prerogatives that most of their respective national parliaments enjoy, the members have also, on the whole, been quick to assert and to propose measures that would extend the parliament's effective control over the commission and Council of Ministers. ${ }^{39}$ Though in recent years the European Democratic Union (UDE), the Gaullist faction, has increasingly injected discordant, nationalistic overtones into the debates at Strasbourg, the general pro-European tenor of the proceedings appears as a commonly shared norm of conduct. Thus the hypothesis is that the more strongly this norm is felt by the members and reinforced by their participation in the parliament's activity, the more likely it is that these members will become more favorably predisposed to support such measures. The expectation is that the situational and role constraints members encounter in the exercise of their mandate at Strasbourg combine to change their attitudes in the direction of a stronger commitment to European integration.

\section{A QUASI-EXPERIMENTAL DESIGN FOR THE MEASUREMENT OF ATTITUDINAL EFFECTS}

To investigate these hypotheses about the possible attitudinal effects associated with membership in the European Parliament, an interview survey was conducted among parliamentarians from France and Germany in the fall and winter of 1967-1968. ${ }^{40}$ From the parliaments of each country, two samples of legislators were drawn and interviewed about their perceptions and attitudes toward European integration. These legislators were extensively probed on their views of economic and political integration and questioned about the circumstances and personal motives surrounding nomination to the parliament. The first sample comprised all the French and German delegates to the European Parliament. ${ }^{41}$ This sample was treated as a "test group," namely a group

${ }^{\text {as }}$ Van Oudenhove, The Political Parties in the European Parliament, p. 220.

* See, inter alia, Furler Report, Parlement Européen, Report on the Powers of the European Parliament, Document 31, 1963-64; Vredeling Report, Parlement Européen, Rapport fait au nom de la Commission de l'agriculture relative à un réglement concernant les conditions du Fonds européen d'orientation et de guarantie aqricole, Document 81, 1963-64; and, the two Vals reports, Parlement Européen, Rapport sur le renforcement des pouvoirs budgétaires du Parlement Européen, Document 28, 1964-65, and Rapport sur les propositions de la Commission de la Communauté Européenne au Conseil, Document 34, 1965-66.

${ }^{*}$ For a full presentation of the research design and questionnaire used, see Henry H. Kerr, Jr., "The European Parliament and European Integration: The Effects of Participation in an International Parliamentary Assembly," (unpublished Ph.D. dissertation, The University of Michigan, 1970).

${ }^{41}$ Of the 36 delegates sent to Strasbourg from the Bundestag, 29 were interviewed, and of the 24 delegates from the French National Assembly, all were 
of national legislators who had been exposed to the stimuli-new information, international contact, non-national roles, and group normsassociated with the learning experience that participation in its activities may constitute. The second sample was a randomly drawn selection of 73 national legislators who had never been members of an international parliamentary assembly. As non-members, these legislators constituted a "control group" whose responses are compared with those of the "test group" in order to detect the attitudinal effects, if any, of participation in the parliament.

This research design is what Campbell and Stanley have called a "static-group comparison." It is a "design in which a group which experienced $\mathrm{X}$ is compared with one which has not, for the purpose of establishing the effect of $X$." $X$ in this design is the experience of working in the parliament. In contrast to a true experimental design, it has a distinct drawback in that the differences observed between the test and control groups may be attributable to "the differential recruitment of persons making up the [two] groups." 42 Were it discovered, for instance, that the French and German members of the parliament are more favorable (or less opposed) toward political unification of the six member states than their national colleagues, this difference might be attributable to the systematic recruitment of legislators predisposed to favor integration rather than to the experience of participating in the parliament. The high pro-European sentiment often observed among the socialist, christian democratic, and liberal groups thus may merely reflect the self-selection of pro-European legislators to the parliament. As Haas observed in the case of the Common Assembly of the ECSC,

very few, if any, individual members were persuaded to the federalist creed as a result of their work in Strasbourg. With the exception of perhaps fifteen members, the bulk was more or less in favour of integration before they ever took up their international mandate. ${ }^{43}$

In a study of Scandinavian legislators sent to sessions of the Consultative Assembly of the Council of Europe, Bonham came to the same conclusion. Using a research design similar to that of this study, Bonham drew random samples of national legislators from the Danish, Swedish, and Norwegian parliaments who had never participated in

interviewed. The reasons for failure to interview seven of the deputies in the German delegation were as follows: four refused, two were hospitalized throughout the conduct of the survey, and one died.

Donald T. Campbell and Julian C. Stanley, Experimental and Quasi-Experimental Designs for Research (Chicago: Rand McNally, 1964), p. 12.

${ }^{4}$ Haas, The Uniting of Europe, p. 437. 
an international assembly and compared their positions on issues related to Nordic and European cooperation with those of delegates who had been members of the Consultative Assembly for four years or longer. Although he found that the delegates were, on the whole, much more favorable toward these issues than their national colleagues, he attributed these attitudinal differences to the recruitment process since approximately three-quarters of the delegates reported that they were chosen to attend the assembly because of their strong interest in European affairs. His conclusion was that since interest in European questions is an important criterion for selecting the delegates, these parliamentarians may be favorably disposed toward political integration before they first go to Strasbourg. ${ }^{44}$

In this study, it was possible to estimate more precisely the effects attributable to self-selection. Since the delegates were interviewed at a single point in time, the direct estimation of these effects by comparison of pre- and post-measurements was precluded. It is possible, however, to make a number of indirect tests of the internal validity of differences in attitudes and perceptions observed between members of the European Parliament (the test group) and non-members (the control group). In the first place, if the magnitude of effects increases with length of membership in the test group, then it is likely that these effects are the results of participation and not self-selection. As Hyman suggested,

if the experience was actually selected on the basis of an initial trait or attitude, then we would expect no difference in the attitude between respondents [within the test group], no matter what the length of experience. ... Only if the attitude were a developmental product of experience, would it change with the magnitude of experience. ${ }^{45}$

In other words, if the members' attitudes toward political unification, for example, were to show an increase in favorableness (or a decrease in hostility) by length of membership, one would have partial support for the inference that participation produces attitudinal changes. ${ }^{48}$ Thus,

" Bonham, Journal of Common Market Studies, Vol. VIII, No. 4, pp. 334-335.

${ }^{25}$ Herbert Hyman, "Problems in Treating Relationships between Two Variables," in Hyman (ed.), Survey Designs and Analysis, (Glencoe: The Free Press, $1960)$, p. 199.

${ }^{10}$ It is possible that the length of membership may merely reflect a more general process of maturation, but this possibility would hold only if all members entered the parliament at the same age, and this is not the case. There is, however, a slight increase in the age of the respondents by length of membership, but the differences in mean age between categories of length of membership used in later analysis are not pronounced. Furthermore, since attitudes toward European integration tend to be negatively correlated with age, a finding that the members' attitudes are positively related to length of membership would mean that this relationship is running against the expectation of a decline in the degree of 
length of membership is a major independent variable. Secondly, if differences in support for integration between members and nonmembers are attributable to the self-recruitment of members who, because of strongly held prior convictions, volunteered to serve in the parliament, these self-recruited legislators ought to differ in their perceptions and attitudes toward European issues from those legislators who were unwilling to volunteer. If, on the other hand, both volunteers (self-recruits) and non-volunteers (party-recruits) within the test group do not differ one from the other on these issues, but differ instead in similar directions from the control group, then it is reasonable to infer that the effects associated with membership in the parliament are due to the learning experience and not to self-selection.

From the members' own accounts of the circumstances of their nomination to the parliament, these two basic types of recruitment patterns emerge. Exactly 60 percent reported that they initiated their own candidacy to the parliament, and 40 percent indicated that it was their national parliamentary group which recruited them, occasionally against their own wishes, for nomination as delegates to Strasbourg. As table 1 shows, the strong relationship between how members were recruited to the parliament and how they first became interested in European affairs is evidence that this breakdown of the sampled members into two groups-self-recruits and party-recruits-does, in fact, measure the degree of voluntarism present in their recruitment. Self-

TABLE 1. TYPE OF RECRUITMENT TO THE EUROPEAN PARLIAMENT BY ORIGINAL INTEREST IN EUROPEAN QUESTIONS

\begin{tabular}{|c|c|c|}
\hline $\begin{array}{l}\text { Occasion for Original } \\
\text { Interest in European } \\
\text { Questions }\end{array}$ & Self-Recruits & Party-Recruits \\
\hline Purely Accidental & $2.2 \%$ & $8.7 \%$ \\
\hline Second Party & 20.0 & 73.9 \\
\hline Consequence of Career & 33.3 & 13.0 \\
\hline Reflections on a Historical Event & 6.7 & - \\
\hline Own Personal Beliefs & 37.8 & 4.4 \\
\hline $\begin{array}{c}\text { Total } \\
N^{a}=\end{array}$ & $\begin{array}{l}100.0 \% \\
(45)\end{array}$ & $\begin{array}{c}100.0 \% \\
(23)\end{array}$ \\
\hline
\end{tabular}

- The total $\mathrm{N}$ is larger than the sample size because this question allowed for multiple responses.

Chi-square is significant at .001 .

support for integration by age. Thus, the use of length of membership as an independent variable is a stronger test for the presence of attitudinal effects than first meets the eye. On the relationship between age and attitudes toward European integration, see Ronald Inglehart, "And End to European Integration?" The American Political Science Review, March 1967 (Vol. LXI, No. 1), pp. 91-105. 
recruits were much more likely than party-recruits to have become interested in European questions as a result of their own personal beliefs or as a consequence of the career paths they chose. Especially noteworthy is that 74 percent of the party-recruits became interested in European questions only at the urging of a second party (who was usually the same party who recruited them to the parliament). In other words, the party-recruits' interest in European politics was largely coterminous with appointment to the parliament, while over threequarters of the self-recruited members reported that their interest was antecedant to their nomination.

A parallel pattern is seen in the response of the non-members who were asked whether they were interested in being nominated to the European Parliament. Those who gave affirmative responses are what might be called potential volunteers, and those who expressed no interest, non-volunteers. That this breakdown also measures the degree of voluntarism is seen in its relationship to the degree of the non-members' interest in the parliament's activities. As table 2 clearly shows, potential volunteers are far more interested in the parliament's activities than non-volunteers. Potential volunteers also pay much closer attention to what occurs in Strasbourg than do those national legislators who are not ready to volunteer for service in the parliament. This

TABLE 2. DEGREE OF VOLUNTARISM AMONG NON-MEMBERS BY INTEREST IN THE EUROPEAN PARLIAMENT AND BY ATTENTION PAID TO DECISIONS OF THE EUROPEAN PARLIAMENT

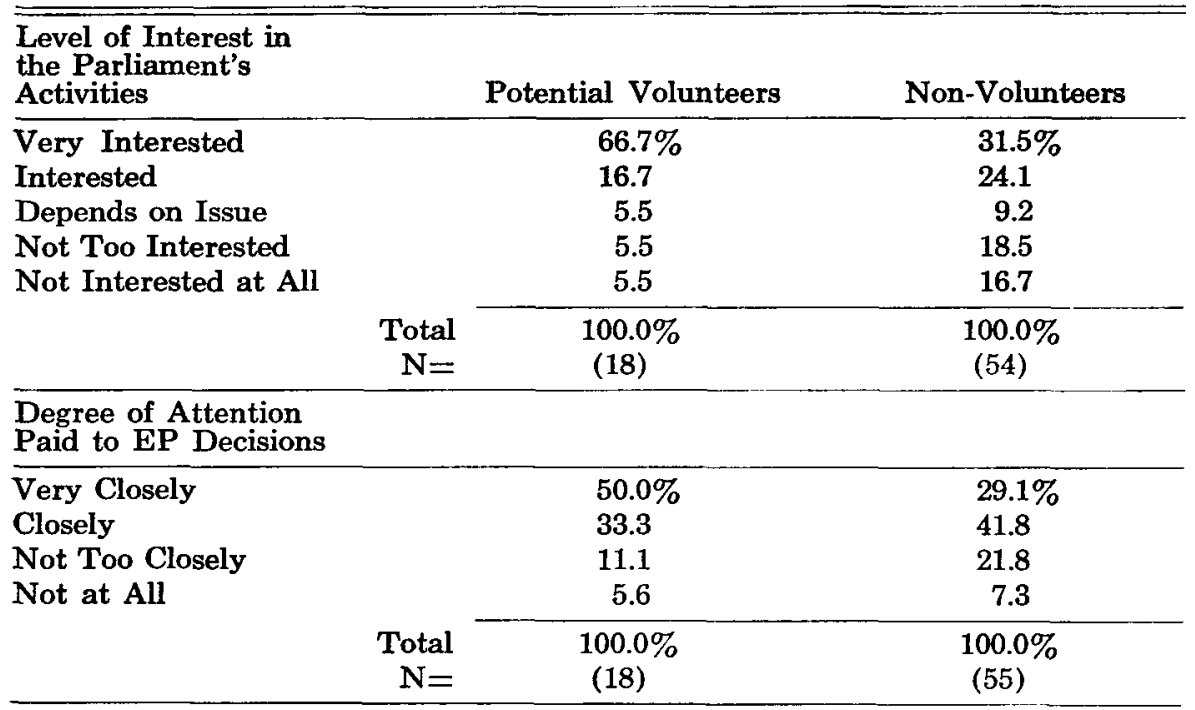

In both instances, chi-square is significant at .05 . 
parallel between the motivations of self-recruited members already at Strasbourg and those potential volunteers in the national parliaments suggests that the self-recruits are motivated to participate in the parliament as a result of a compelling interest in European questions developed prior to their membership. A strong element of self-selection is therefore apparent in the recruitment process.

The effects of the degree of voluntarism on the participants' orientations are also observable in the differences in the kinds of satisfactions and dissatisfactions self-recruits and party-recruits associate with their experiences in the parliament. The self-recruited members derive proportionately greater satisfaction from the opportunity to accomplish specific legislative tasks, to work out common policies, and to contribute to a common spirit of cooperation than they do from the opportunity for personal contact with foreign colleagues, while the converse holds for party-recruits (see table 3). These differences suggest

\section{TABLE 3. THE MOST SATISFACTORY EXPERIENCE ASSOCIATED WITH PARTICIPATION IN THE PARLIAMENT BY TYPE OF RECRUITMENT}

\begin{tabular}{|c|c|c|}
\hline $\begin{array}{l}\text { The Most Satisfying } \\
\text { Experience }\end{array}$ & Self-Recruits & Party-Recruits \\
\hline Material Advantages & $2.6 \%$ & - \\
\hline Wider Personal Horizons & 7.9 & $10.0 \%$ \\
\hline Personal Contact & 28.9 & 45.0 \\
\hline $\begin{array}{l}\text { Opportunity to Exercise } \\
\text { Personal Influence }\end{array}$ & 18.4 & 20.0 \\
\hline $\begin{array}{l}\text { Accomplishment of a Legislative } \\
\text { Task or Policy } \\
\text { Contribution to Common }\end{array}$ & 28.9 & 5.0 \\
\hline $\begin{array}{l}\text { Contribution to Common } \\
\text { Spirit of Cooperation }\end{array}$ & 13.2 & 4.0 \\
\hline Other & - & 15.0 \\
\hline $\begin{array}{l}\text { Total } \\
N^{*}=\end{array}$ & $\begin{array}{l}100.0 \% \\
(38)\end{array}$ & $\begin{array}{l}100.0 \% \\
(20)\end{array}$ \\
\hline
\end{tabular}

- The total $\mathrm{N}$ is greater than the sample size because the question allowed for multiple responses.

Chi-square is significant at .05 .

that the self-recruits are more task and policy oriented and view their participation more in professional terms than do the party-recruits. The differences in the kinds of dissatisfactions expressed by these two groups suggest the same conclusion. Although these differences are not statistically significant, the self-recruits appear more likely to be dissatisfied over the failure of the parliament to achieve common policies or tasks and much less concerned about personal irritations. They are also less sensitive to national slights than are party-recruits (see table 4). In brief, the self-recruits appear to view their work at Strasbourg main- 
TABLE 4. THE MOST DISSATISFACTORY EXPERIENCE ASSOCIATED WITH PARTICIPATION IN THE PARLIAMENT BY TYPE OF RECRUITMENT

\begin{tabular}{|c|c|c|}
\hline $\begin{array}{l}\text { The Most Dissatisfying } \\
\text { Experience }\end{array}$ & Self-Recruits & Party-Recruits \\
\hline Strictly Personal & - & $19.0 \%$ \\
\hline Unsatisfying Personal Relations & $8.7 \%$ & 14.3 \\
\hline Lack of Personal Influence & - & 4.8 \\
\hline Failure of a Particular Policy & 13.0 & 9.5 \\
\hline Failure to Adopt Common Policies & 34.8 & 14.3 \\
\hline Absence of Legislative Power & 26.1 & 23.8 \\
\hline Other & 17.3 & 14.3 \\
\hline $\begin{array}{c}\text { Total } \\
\mathrm{N}=\end{array}$ & $\begin{array}{l}100.0 \% \\
(23)\end{array}$ & $\begin{array}{l}100.0 \% \\
(21)\end{array}$ \\
\hline
\end{tabular}

Chi-square is not significant.

ly in terms of strong policy commitments, while the party-recruits view it largely as a personal experience.

These differences in motivation and interest invested in the parliamentary work at Strasbourg between self-recruited and party-recruited delegates do not necessarily imply that participation in the activities of the parliament has no influence on their attitudes. It suggests instead that subsequent analysis of differences observed between members and non-members of the parliament must tease out the effects, if any, attributable to self-recruitment. Since the differences in motivation and interest between self-recruits and party-recruits closely parallel those observed between potential volunteers and non-volunteers in the home parliaments, a method of detecting these effects emerges from this comparison. If self-selection accounts for differences in the perceptions and attitudes expressed by members and non-members, then one ought to except that the attitudes of those legislators who volunteered or stand ready to volunteer themselves for nomination to the parliament-that is, self-recruits and potential volunteers-do not substantially differ one from the other, but do differ strongly (and in the same direction) from the attitudes held by those who did not or will not willingly volunteer, namely party-recruits and non-volunteers. Whether or not selfselection obviates the possibility that participation results in a learning process is thus an empirical question to be settled by observing the variation in attitudes held by potential volunteers and self-recruits, on the one hand, and non-volunteers and party-recruits, on the other.

\section{PERCEPTIONS OF EUROPEAN INTEGRATION: COGNITIVE EFFECTS}

The general aim of this study was to detect two broad categories of effects that participation in the European Parliament may produce. 
For analytical purposes, the attitudes an individual holds toward a class of objects can be separated into cognitive and affective components. According to Scott, "first . . . is the set of cognitive attributes by which the person understands the object in an intellectual way. This is his view of the 'inherent' characteristics, which he regards as independent of his own response to them." More specifically, the cognitive component involves what a person knows about an object, how he perceives it, and how central the object is to his beliefs. Secondly, an attitude "may contain an affective component, representing a liking or disliking for the focal object. This is usually associated with perceived attributes of which the person either approves or disapproves."47 The separation of attitudinal dimensions into these two components also appears to be justified by findings based on the study of the effects of participation in international programs of exchange and cooperation. A tourist who sojourns in a foreign country, for example, tends to return to his homeland with less stereotyped impressions of the host country and richer, more accurate perceptions of his hosts. His predisposition to like or to dislike the policies and stands of his hosts and their country frequently remains unchanged, but the cognitive component of these attitudes often becomes more refined and differentiated as a result of the foreign experience. ${ }^{48}$ Finally, since these findings are in keeping with the results of this study, it is useful to maintain this distinction throughout the following presentation.

The questions asked of the samples of French and German parliamentarians permitted an analysis of three general classes of cognitive effects that participation in the European Parliament may have on their perceptions of European economic and political integration. At the most elementary level, participation in the parliament's activities may increase the members' awareness and knowledge of the issues related to integration. As a result of long hours devoted to the preparation of resolutions on these issues, members may very likely become more knowledgeable about European integration than their national colleagues who are relatively isolated from international sources of information. A corollary of this proposition is the hypothesis that the more information an individual legislator possesses about integration, the more differentiated and complex is the cognitive component of his attitudes toward integration.

And if the information is of fairly wide scope and reasonably accurate, an increase in the number of attributes [that a member of

${ }^{47}$ Scott, in Kelman (ed.), International Behavior, p. 72.

${ }^{48}$ For a comprehensive review of these findings, see Ithiel de Sola Pool, "Effects of Cross-National Contact on National and International Images," in ibid, pp. 113-119. 
the Parliament, for example, can bring to bear in assessing integration] would presumably be accompanied by an increase in the dimensional complexity of the attribute [i.e., cognitive] system. ${ }^{49}$

In other words, the experience of being exposed to a wide range of information on integration very likely increases the number of evaluative dimensions by which members assess the issues. A final corollary of these propositions is the hypothesis that the larger the mass of information an individual acquires about integration as the object of an attitude, the more likely it is that this object will become more central to the individual's attitudes. ${ }^{50}$ It is, therefore, expected that participation in the parliament increases the participants' interest in European integration and that this attitudinal dimension comes to play a more prominent role in the members' perceptions of foreign affairs.

The first question is: how much information do members add to their general store of knowledge about integration as a result of their activities in the parliament? By their own testimony, the members perceive this experience as an unusual opportunity to develop a broader view of European integration. In response to a question about the advantage of membership, more than 60 percent of the French and German delegates interviewed cited exposure to new information, especially in the form of personal contact with foreign colleagues, as a principal advantage. Typical of these responses was the comment of a French Gaullist who, though generally disenchanted with his experience, came to the conclusion that "if anything, it's an opoprtunity to rub shoulders with parliamentarians from other countries and to realize, as a consequence, that they have the same worries as we. Something is, after all, learned." External evidence appears to justify this deputy's observation. Members of the European Parliament are exposed to an enormous amount of information during the exercise of their mandate. In all, the average member spends about 60 working days, or twelve working weeks, per year in attendance at various kinds of sessions connected with the parliament. Since this represents an enormous investment in time and personal resources it would come as a surprise if members of the parliament were not better informed about European affairs than their national colleagues.

A direct measure of the amount of information possessed by the members was not included in the questionnaire. However, the samples of French and German legislators were asked what source of information they used in order to keep up with current developments within the European Community. Although it is not entirely permissible to equate

${ }^{+}$Scott, in ibid., p. 94.

${ }^{50}$ Newcomb, Turner and Converse, Social-Psychology, pp. 58.65. 
the kinds of information used by a legislator to keep informed about European issues with the amount of information he has actually stored about these issues, there is some justification to the inference that legislators who rely extensively upon international sources of information probably have broader perceptions and better information about these developments than legislators who do not. This is, in fact, what was found. Members of the European Parliament said they relied upon international sources of information, particularly documents provided by the parliament and other EEC authorities, 48 percent of the time, while non-members reported that they relied upon these sources only 32 percent of the time (see table 5). It is noteworthy that members tend to depend less upon the national press and upon organs of their national parties and legislatures for information, and more upon documents provided by EEC agencies, than do non-members. This finding suggests that members of the European Parliament are enmeshed in an European communications network and that their perceptions of Euro-

TABLE 5. SOURCES OF INFORMATION USED TO KEEP INFORMED OF CURRENT DEVELOPMENTS WITHIN THE EUROPEAN COMMUNITY BY MEMBERSHIP IN THE EUROPEAN PARLIAMENT

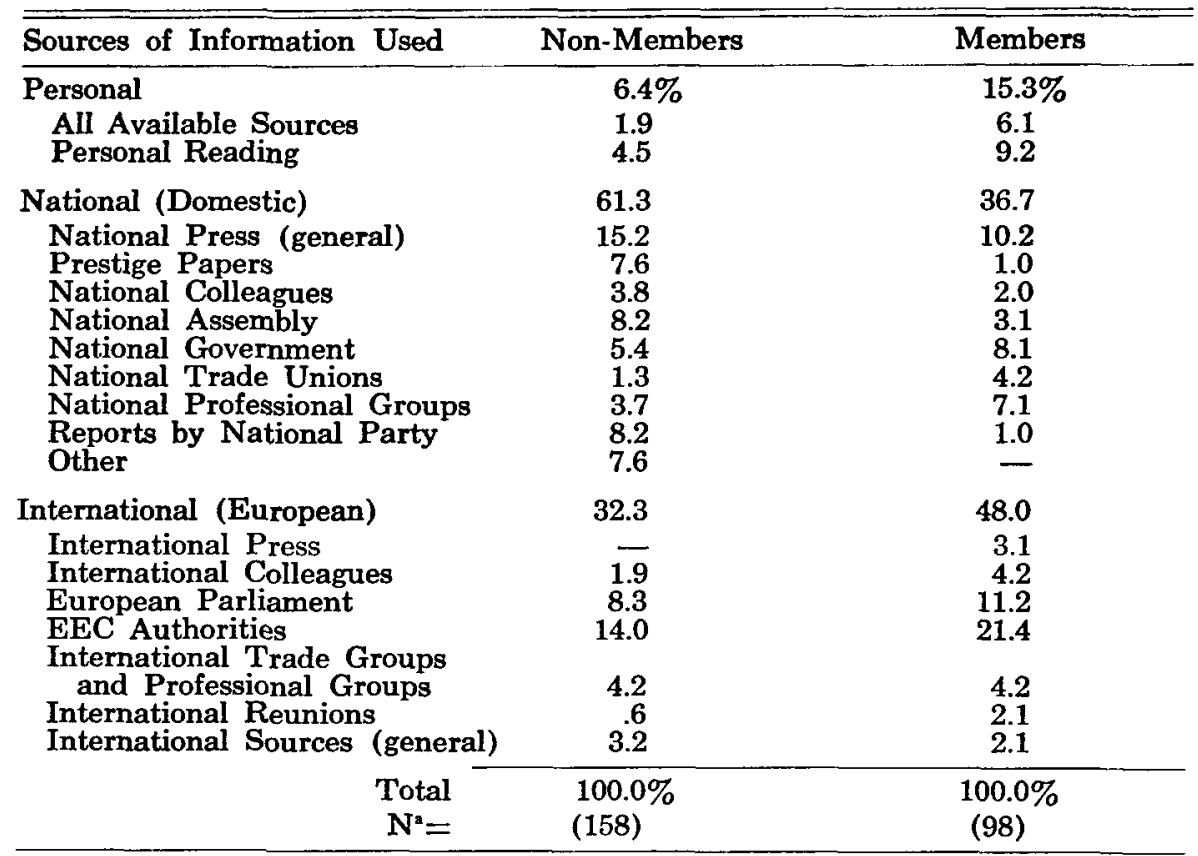

- The total $\mathrm{N}$ is larger than the sample size because the question allowed for mutiple responses.

Chi-square is significant at .001 . 
pean issues are shaped more by information acquired through European channels of communication than by national ones.

Once the tendency toward self-exposure to these channels is controlled among non-members, these differences are accentuated. Recall that non-members who expressed an interest in nomination to the European Parliament reported a higher frequency of attention to the parliament's activities than did those non-members who expressed no interest whatsoever (see table 2 above). Given these self-reported levels of attention, the hypothesis is that these potential volunteers attend more to international sources for information about European affairs than do the non-volunteers. As table 6 shows, ${ }^{51}$ the possible effects of selfselection are very much in evidence; the potential volunteers appear sufficiently motivated by their interest in the European Parliament to seek out international sources of information about these issues at a level equal to that of self-recruited members already at Strasbourg. One may be led, as a result, to conclude that the overall differences in attention paid to these international sources between members and nonmembers, as observed in table 5, are attributable to self-recruitment, not to participation.

\section{TABLE 6. CONTENT OF SOURCES OF INFORMATION USED BY MEMBERSHIP IN THE EUROPEAN PARLIAMENT, BY DEGREE OF VOLUNTARISM, AND BY LENGTH OF MEMBERSHIP}

\begin{tabular}{|c|c|c|c|c|c|c|c|}
\hline \multirow[b]{3}{*}{$\begin{array}{l}\text { Sources } \\
\text { of Infor- } \\
\text { mation }\end{array}$} & \multicolumn{2}{|c|}{ Non-Members } & \multicolumn{5}{|c|}{ Members } \\
\hline & \multirow{2}{*}{$\begin{array}{l}\text { Poten- } \\
\text { tial } \\
\text { Volun- } \\
\text { teers }\end{array}$} & \multirow[b]{2}{*}{$\begin{array}{l}\text { Non- } \\
\text { Volun- } \\
\text { teers }^{2}\end{array}$} & \multicolumn{2}{|c|}{ Type of Recruitment } & \multicolumn{3}{|c|}{ Length of Membership } \\
\hline & & & $\begin{array}{c}\text { Self- } \\
\text { Recruits }\end{array}$ & $\begin{array}{c}\text { Party- } \\
\text { Recruits }\end{array}$ & $\begin{array}{c}0-2 \\
\text { Years }\end{array}$ & $\begin{array}{c}3-6 \\
\text { Years }\end{array}$ & $\begin{array}{c}7+ \\
\text { Years }\end{array}$ \\
\hline $\begin{array}{l}\text { National } \\
\text { Sources }\end{array}$ & $36.8 \%$ & $76.7 \%$ & $36.5 \%$ & $37.5 \%$ & $55.9 \%$ & $37.8 \%$ & $7.7 \%$ \\
\hline $\begin{array}{l}\text { Inter- } \\
\text { national } \\
\text { Sources }\end{array}$ & 63.2 & 23.3 & 63.5 & 62.5 & 44.1 & 62.2 & 92.6 \\
\hline $\begin{array}{r}\text { Total } \\
\mathrm{N}=\end{array}$ & $\begin{array}{l}100.0 \% \\
(38)\end{array}$ & $\begin{array}{l}100.0 \% \\
(120)\end{array}$ & $\begin{array}{l}100.0 \% \\
(52)\end{array}$ & $\begin{array}{c}100.0 \% \\
(40)\end{array}$ & $\begin{array}{c}100.0 \% \\
(34)\end{array}$ & $\begin{array}{c}100.0 \% \\
(37)\end{array}$ & $\begin{array}{c}100.0 \% \\
(27)\end{array}$ \\
\hline
\end{tabular}

- Chi-square is significant at .001.

b Chi-square is significant at .01 .

s1 For purposes of brevity and clarity, the multiple categories reported in table 5 have been collapsed under the two general headings of domestic and international sources of information. By carefully rechecking the responses of those parliamentarians who cited personal sources of information to this and similar questions, it was possible to determine the domestic or international character of their personal sources and thus to reassign these parliamentarians to one or the other of the two general categories. For a detailed explanation, see Kerr, "The European Parliament and European Integration," pp. 105-106. 
Upon closer examination of table 6, this conclusion does not appear to be fully warranted, however. Although the equally high level of attention paid to these sources by both potential volunteers and selfrecruits may suggest that the self-recruits were strongly predisposed to follow European affairs via these channels prior to their nomination to Strasbourg, the sharp difference of nearly 40 percent between nonvolunteers and party-recruits cannot be explained by self-recruitment. It is striking that the party-recruits, who had to be corralled into accepting nomination, do not differ in their degree of reliance on international sources from that of the self-recruits. This pair of observations supports a minimal hypothesis that as party-recruited delegates become involved in the work of the parliament, they come to rely more and more upon information made available to them through participation in its legislative activities. It tends to corroborate the Gaullist delegate's own evaluation of his experience (as a party-recruit): membership in the parliament gives these recalcitrant delegates an unusual opportunity to develop a broader outlook on European integration. "Something is, after all, learned." Moreover, when the level of attention paid by the members to international sources is broken down by their length of membership in the parliament, there is a steady increase in degree of reliance upon these sources of information among both self-recruited and party-recruited members, and a consequent decrease in their use of national sources. This developmental increase among all members by the amount of their international parliamentary experience is particularly strong evidence in support of the general contention that the differences between members and non-members are, in a goodly measure, the product of participation. Self-recruitment notwithstanding, the attention paid by self-recruits to international sources increases with experience in the parliament at a rate equal to that of party-recruits.

All in all, these findings persuasively support the general hypothesis that participation in the parliamentary work at Strasbourg makes the members better informed about European questions, in terms of sheer quantity as well as diversity of information. In short, the expertise of the members is substantially enhanced. This contention is further borne out by the reports of non-members who were asked to identify the legislators in their respective national assemblies whom they considered as the experts in European matters. Of the legislators named $(\mathrm{N}=221), 65.6$ percent of them were members of the European Parliament. When broken down by country, this percentage increases to a remarkable 80.2 percent $(\mathrm{N}=96)$ in Germany and drops to 56.5 percent $(\mathrm{N}=125)$ in France. Despite these country differences, in relation to their small numbers in the two national parliaments of approximately 7 and 5 percent, respectively, members of the parliament are disproportionately named as experts in these questions by their na- 
tional colleagues. Thus it seems that the knowledge and information that members acquire in the course of their legislative activity at Strasbourg enhances the expertise attributed to them.

A corollary of the proposition that members of the European Parliament gain in expertise as a result of their experience is the hypothesis that as they acquire greater amounts of information about European affairs, it becomes more likely that they will learn to use a larger number of attributes to assess these issues and to discriminate more finely among them. Analysis of responses to two separate questions, which serve as approximate indicators of the legislators' discriminatory ability, tend to support this hypothesis. First, in responding to a question about their preferences for the type of terminal agreement among the six member states of the EEC, many interviewees voluntarily made a distinction between short- and long-term goals. Typical of this kind of response was that of a German Christian Democrat who, instead of unequivocably stating his preference for political federation, felt compelled to observe that to attain this level of political cooperation, it was first necessary to move through several intermediate stages, from a customs union to an economic union and later to complete federation. Since the question was close-ended and did not prompt for distinctions of this kind, the presence or absence of these voluntary comments is an adequate measure of the respondent's natural tendency to make finer distinctions about preferences on an issue of central importance to most legislators' attitudes toward European integration. The pattern of results in this analysis is identical to that observed for self-reported levels of attention paid to international sources of information: whereas potential volunteers made this distinction with a frequency (of about 50 percent) equal to that of both and self- and party-recruited members of the parliament, non-volunteers did so at a rate of seventeen percentage points less than party-recruits. The members' tendency to expand upon their judgments on this issue also markedly increased by length of membership in the parliament, from 25 percent among members with less than three years of service to 52.6 and 85.7 percent among those members with, respectively, three to six and seven or more years of service. In a second question, which asked the respondents to make as many distinctions as they perceived among the positions of the major national political parties toward political unification, ${ }^{52}$ the exact same pattern of results was uncovered. Although, on the whole, German legislators saw far fewer differences among the positions of the Christian Democratic Union (CDU), Free Democratic Party (FDP), and Social

\footnotetext{
${ }^{62}$ The question was: "What are, in your opinion, the principal differences among .... (the major political parties were named) ... with respect to political unification of the six member states of the EEC?"
} 
Democratic Party (SPD) than French deputies perceived among the Federation of the Democratic and Socialist Left, the independent republicans, the Popular Republican Movement (MRP), and the Union for the New Republic (UNR) (which is a telling indicator of the respective level of controversy that this issue evoked in public debates within the two countries in 1967 and 1968), the non-volunteers saw substantially fewer differences than did the party-recruits, and a strong development increase in this tendency was observed among the members by length of service in the parliament. ${ }^{53}$ This combined evidence supports the conclusion that the high level of information about European questions, acquired by members through direct exposure and by potential volunteers through self-exposure to European communications channels, heightened their sensitivity to slight differences among party positions on these questions. It follows that since participation in the European Parliament tends to make the members more aware and better informed about the issues, they are more apt to make finer discriminations among them.

One last link in this chain of argument remains to be investigated. It is the proposition that the more information an individual acquires about a subject, the more likely he is to develop a stronger interest in it. The relationship between interest and information clearly runs in both directions: ${ }^{54}$ as members of the parliament are exposed to greater amounts of information and acquire more expertise in European affairs, their interest in them is stimulated and their attention to information about them consequently increases. In addressing the interest side of the relationship, the question is: does participation in the parliament increase the members' interest in European integration and make this issue more central to their concerns? Given the findings already presented, a positive answer to this question would strengthen the whole line of inquiry. If European questions do become more central to the members' interests, then it probably follows that these members come away from their experience better informed just as it followed that if they were better informed, their perceptions would become more differentiated.

Two sets of items, included only in the German version of the questionnaire, provided a measure of the centrality of European questions to the concerns of the German sample. At the outset of the interview, the German respondents were asked to identify what they considered to be the most important problem facing the Federal Republic of Germany. Since the exact nature of the interview topic was not revealed beforehand, responses to this open-ended question are an accu-

See Kerr, "The European Parliament and European Integration," pp. 114-119.

${ }^{4}$ See Newcomb, Turner, and Converse, Social-Psychology, pp. 60-61. 
rate indicator of what issues were then most central to their concerns. The results strongly suggest that participation in the parliament does increase the members' general interest in European questions. Among the non-members in the Bundestag, potential volunteers cited European issues three times more frequently than domestic problems (25 percent compared to 8.3 percent), while the reverse held for non-volunteers who mentioned domestic problems ten times more frequently than European issues (3.2 percent compared to 34.3 percent). Among the German members of the parliament, both self-recruits and party-recruits gave responses almost identical to those of the potential volunteers and showed a strong progressive increase in the absolute level of their interest in European problems by length of service in the assembly. Among members with less than three years of service, only 6.7 percent identified European problems as the most important, compared with 30 percent among members with three to six years of service and 46.2 percent among those who had been members for seven or more years.

The next series of questions provided a basis for ascertaining more exactly how the experience of participating in the European Parliament tends to shift the importance attached to a variety of issues. By comparing the importance attached to European unification across a set of issues, it is possible to obtain an even better estimate of its relative centrality. As table 7 reveals, the same pattern of results holds for this set of four issues. European political unification is by far the most central issue to German members of the Parliament.55 Unification was considered to be very important by 85.7 percent of the members, and of all the issues, this was the highest percentage in this category. Furthermore, only 54.2 percent of the non-volunteers attached the same degree of importance to political unification. On the other hand, that 67.9 percent of the members perceived German reunification as a very important issue is not insignificant; however, it is the relative importance members attach to it in relation not only to that of unification within the EEC, but also in comparison with the extremely high consensus on its importance among all non-members, that bears attention. It seems that participation in the parliament increases the significance attached by German members to European political unification at the expense of concern for German reunification.

This finding is a telling indication of a shift in the centrality of the members' concerns as well as a notable change in orientation, for it also holds that the longer a German legislator is a member of the parliament, the more concerned he becomes about European unification and the less concerned about German reunification. Among those German

\footnotetext{
${ }^{\circ 5}$ The differences in responses to these questions between self-recruits and partyrecruits are not reported in table 7 since they were, in all cases, nearly identical.
} 


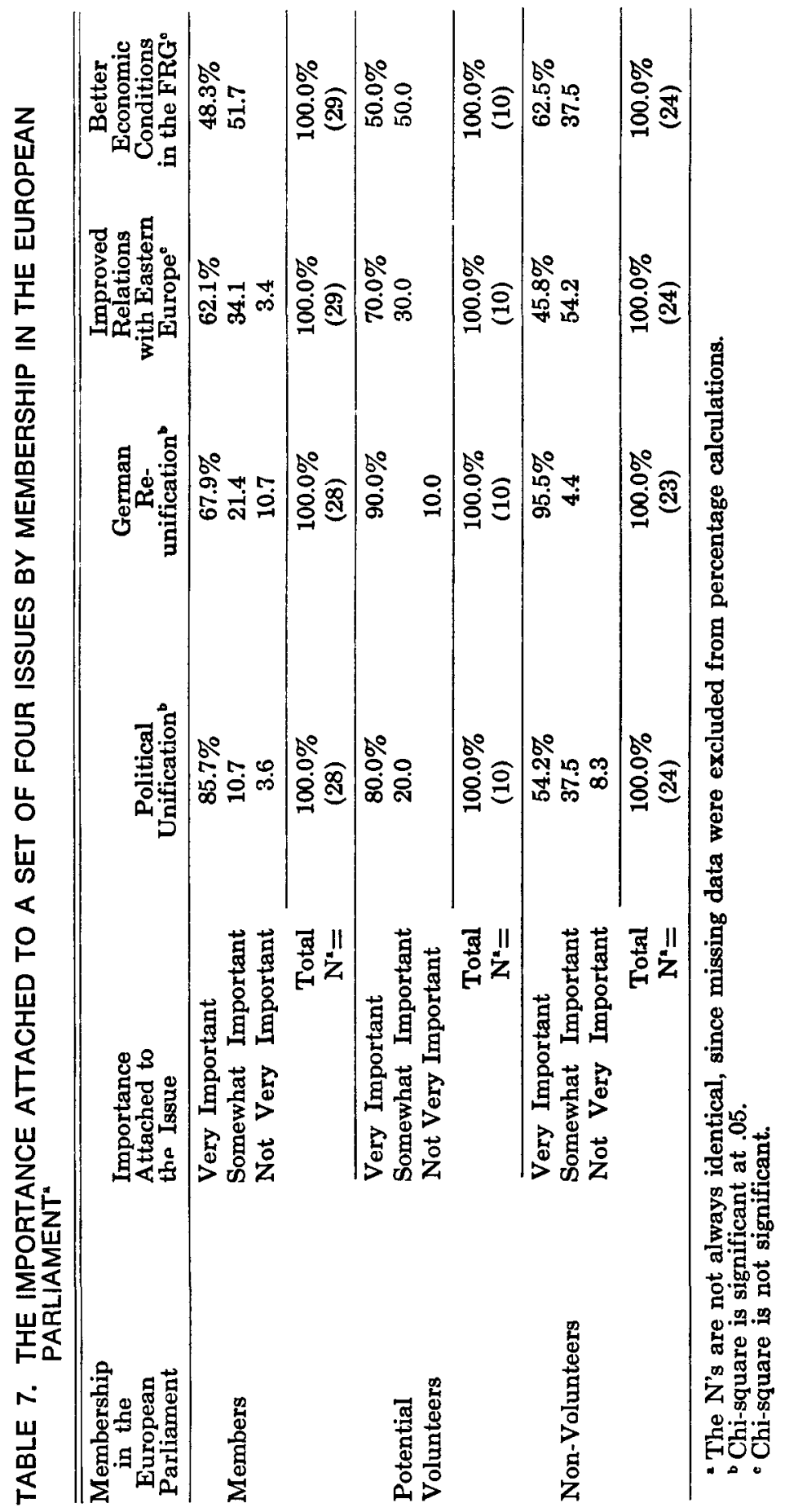


delegates who were members for six years or longer, only 53.3 percent consider the issue of reunification as very important, 26.7 percent as somewhat important, and 20 percent as not important at all $(\mathrm{N}=15)$. This compares with 76.2 percent, 23.8 percent, and 0 percent for these respective categories among those who were members for five years or less $(\mathrm{N}=13)$. The opposite relationship holds for the issue of political unification of the six member states of the EEC. This shift in the relative magnitude of importance from domestic to European issues is also reflected in the issues of better economic conditions at home and relations with Eastern Europe. Both the members of the parliament and potential volunteers perceive this European issue as more important than the domestic one, while the contrary holds for the nonvolunteers. Also, the members' concern for improved economic conditions at home drops sharply with increased length of membership: among those delegates who were members for six years or longer, only 33.3 percent considered this issue to be very important and 66.7 percent as somewhat important $(\mathrm{N}=15)$, as compared to 64.7 and 35.3 percent for these two categories among those who were members for five years or less $(N=14)$. Though the evidence is not massive, especially since the inference is based upon differences in the two high categories, it tends to support the hypothesis that participation in the European Parliament makes European political unification more central, and domestic issues less central, to the members' concerns.

It is noteworthy that this finding fits the pattern of earlier expectations. Those German legislators who appear to be well informed and to hold highly differentiated cognitions about European questions are the same legislators for whom these questions are extremely importanton the whole, more important than national concerns. It is likely that this relationship also holds for the French sample, in part because the relationship between interest and self-exposure to information which was found among non-members from both France and Germany is very similar to that between the centrality of the issues and information, and in part because all the other relationships presented so far are remarkably alike in the two countries.

The European Parliament thus appears to form a corps of European experts from among the national parliamentarians nominated to participate in its activities. It may seem trivial to observe that the experience of belonging to the parliament increases the amount of information a member possesses about European integration, and patently evident that this increase in level of information leads to an increased differentiation of related cognitions and to more interest in European affairs. Actually, it is not. It is through a sure, but steady, accumulation of legislative expertise in this area that concepts and information related to European integration are probably transmitted to national 
parliaments. If members of the parliament do become more informed, expert, and interested in European matters as a result of this experience, then it may be reasonable to infer that the members carry these effects with them back to the home parliaments. As Haas observed in the case of the parliament's immediate predecessor,

The significance to political integration, then, is the mere fact that the hundred-odd members of the Common Assembly developed into the European parliamentary elite, whose very existence and functioning in the nexus of High Authority, Council of Ministers, and European integration issues has given it [and its members] a unique outlook and channels of communication for carrying out the expanded task of 'parliamentary control' which the new institutions had in store for it. ${ }^{56}$

\section{ATTITUDES TOWARD EUROPEAN INTEGRATION: AFFECTIVE EFFECTS}

Participation in the European Parliament may alter the affective as well as the cognitive component of the members' attitudes toward European integration. As members become involved in the work of the parliament, the strength of their support for integration may increase or, stated more dramatically, the degree of their hostility to integration may diminish. Effects of these kinds are believed to be operative among civil servants appointed to serve in international agencies. Lindberg has suggested that as national civil servants become involved in administrative tasks of the commission at Brussels, they are "engaged" by the decisions taken, become "committed" to European integration, and develop a sense of "community-mindedness." has described similar effects of participation in the specialized agencies of the United Nations. Civil servants who were first opposed or indifferent to the goals of an agency may gradually alter their attitudes as they carry out their tasks. ${ }^{58}$ Similarly, as postulated earlier, national legislators who enter the European Parliament for the first time are exposed to a set of parliamentary traditions and norms which place an exceedingly high value on a strong commitment to regional integration. It is especially within the three cross-national political groups that these norms are visible. As Van Oudenhove commented,

It became more and more the rule for a Christian Democrat, Socialist, or Liberal to have contacts with his like-minded colleagues from other states rather than with those of his compatriots who did not belong to his own party. Thus there arose three ideological

\footnotetext{
- Haas, The Uniting of Europe, pp. 439-440, italics in the original.

- Lindberg, The Political Dynamics of European Economic Integration, p. 84.

Haas, Beyond the Nation-State, p. 112 and pp. 132-133.
} 
communities, each representing one of the traditional trends of thought in Europe. National interests were increasingly subordinated to politico-ideological principles. . . .59

The hypothesis then is that because of group pressures exerted on members to conform to group positions, it is possible that members of these three groups will change their attitudes in the direction of group norms, which, on the whole, imply a strong attachment to integration.

The strength of this norm was, in fact, captured in the interviews with both the members and their national colleagues. Not only did a vast majority of the French and German legislators who were interviewed express deep disappointment at the failure of the parliament to play an important role in the life of the European Community, but there was also complete unanimity among the Socialists, Christian Democrats, and Liberals from both countries that the powers of the parliament ought to be increased (see table 8 ). Not surprisingly, only

TABLE 8. GENERAL SUPPORT FOR INCREASED POWERS OF THE EUROPEAN PARLIAMENT BY MEMBERSHIP IN THE PARLIAMENT AND BY PARTY AFFILIATION

\begin{tabular}{|c|c|c|c|c|c|c|c|c|}
\hline \multirow{3}{*}{$\begin{array}{l}\text { Support for } \\
\text { Increasing } \\
\text { the Powers of } \\
\text { the European } \\
\text { Parliament }\end{array}$} & \multicolumn{8}{|c|}{ Party Affiliation } \\
\hline & \multicolumn{2}{|c|}{ Socialist } & \multicolumn{2}{|c|}{$\begin{array}{l}\text { Christian } \\
\text { Democrat }\end{array}$} & \multicolumn{2}{|c|}{ Liberal } & \multicolumn{2}{|c|}{ Gaullist } \\
\hline & $E P^{*}$ & NEP $^{b}$ & EP & NEP & $\mathbf{E P}$ & NEP & EP & NEP \\
\hline $\begin{array}{r}\text { For } \\
\text { Against }\end{array}$ & $100 \%$ & $100 \%$ & $100 \%$ & $100 \%$ & $100 \%$ & $100 \%$ & $\begin{array}{l}55 \% \\
45\end{array}$ & $\begin{array}{l}36 \% \\
64\end{array}$ \\
\hline $\begin{array}{c}\text { Total } \\
\mathbf{N}=\end{array}$ & $\begin{array}{l}100 \% \\
(17)\end{array}$ & $\begin{array}{l}100 \% \\
(30)\end{array}$ & $\begin{array}{l}100 \% \\
(18)\end{array}$ & $\begin{array}{c}100 \% \\
(25)\end{array}$ & $\begin{array}{r}100 \% \\
(5)\end{array}$ & $\begin{array}{r}100 \% \\
(7)\end{array}$ & $\begin{array}{r}100 \% \\
(13)\end{array}$ & $\begin{array}{r}100 \% \\
(11)\end{array}$ \\
\hline
\end{tabular}

- EP is an abbreviation standing for member of the European Parliament.

- NEP is an abbreviation for non-member of the Parliament.

the French Gaullists expressed any opposition to this principle; the Gaullist members of the parliament tended, however, to be more favorable to an expansion of the parliament's powers than their national colleagues in Paris. Although the respondents were not extensively questioned about the remedies they had in mind, it was the impression of this author that these opinions, particularly those expressed by the members, reflected an "esprit de corps." It appeared that participation in the parliament led to the formation a strong commitment to making the parliament a viable institution.

To investigate the specific hypothesis that participation in this

\footnotetext{
${ }^{50}$ Van Oudenhove, The Political Parties in the European Parliament, p. 21. Also see Forsyth, The Parliament of the European Communities, pp. 27-28.
} 
setting also leads to an increase in the members' level of support for integration or, reciprocally, to a decrease in their level of hostility, the legislators interviewed in this survey were asked more than twenty questions about their positions on European issues. These questions ranged from their positions on political unification and the preferred form of a terminal agreement among the six member states, to adoption of a European flag, from their preference regarding the admission of Spain and Portugal to the EEC to the role of the commission in external and internal economic affairs. The questions touched on almost every aspect of community policy, including issues (such as the creation of an independent European atomic strike force) that are not frequently debated topics. A factor analysis of these questions uncovered five distinct dimensions underlying the legislators' responses: democratic reform of the EEC institutions and practices, economic integration, creation of a common defense force, external relations of the community, and political unification. ${ }^{60}$ The first factor is a cluster of attitudes involving reform of the European Parliament, which encompassed questions of increasing its powers, seating communist delegates, and instituting direct elections, as well as the admission of Spain and Portugal to the EEC and suspension of aid to Greece. It was the high loadings of the last two questions on this dimension that seemed to imply a broad concern with the democratic character of the EEC. The second factor includes an array of attitudes toward the traditional issue of a liberal versus a planned market economy. All of the questions referred to the degree to which the legislators wanted the commission to take an active part in the regulation of the economic affairs of the six. The third factor groups two issues together relating to the creation of an independent European military force. It is particularly interesting to note that these military questions cluster together on an entirely independent dimension, unrelated to the other perceived dimensions of European integration. The fourth factor is a dimension that has to do with relations of the EEC with third countries. The last factor is a sharply defined cluster of issues relating to political unification and is noteworthy because it comprises not only the legislators' views on political unification per se, but also on the degree to which political unification should be accompanied by the introduction of symbols-a common flag and a European identity card-which may arouse a sense of common identity or loyalty among the member populations.

\footnotetext{
${ }^{\circ}$ To uncover these dimensions, 25 questions were factor analyzed. The factors were first defined by a varimax solution and subsequently rotated orthogonally. Finally, an oblique solution was used to obtain the attitude clusters presented here. See Kerr, "The European Parliament and European Integration," pp. 140-143.
} 
All in all, the dimensions revealed by this analysis are theoretically very satisfying. In viewing the many issues associated with efforts to unite Europe, the legislators separate and group them into clearly defined issue areas. European integration is not seen as an undifferentiated process but as several distinct processes. In particular, the economic, political, and military spheres are sharply differentiated from one another. This tendency toward dissociation of the issues into separate spheres is partial corroboration of Hoffmann's distinction between high and low politics:61 from the legislators' positions on high politicsissues related to political and military cooperation-one cannot predict their positions on low politics-issues related to economic integration. Furthermore, this division among policy domains also corresponds to the standard approach to the study of community policy formation. Observers of the European Community usually treat the five dimensions uncovered in this analysis as analytically separate objects of study. The legislators apparently view the issues in much the same way.

From four of these five dimensions, items were chosen to construct attitude scales measuring the overall strength of the legislators' commitment or hostility to further integration within these several spheres of cooperation. ${ }^{62}$ As the totals in table 9 reflect, in the three areas of political unification, democratic reform, and common external policy, the non-Gaullist members of the European Parliament were, on the whole, considerably more positive in their support of these issues than their national colleagues. ${ }^{63}$ In the positive category, the non-Gaullist members are, on the average, 14 percentage points higher in their level of support for these issues than the non-members: 70 percent of the members are strong supporters of political unification compared to 56.4 percent among non-members, 43.6 percent of the members fall in the highest

- See Stanley Hoffman, "Discord in Community: The North Atlantic Area as a Partial International System," International Organization, Summer 1963 (Vol. XVII, No. 3), pp. 521-549, and "Obstinate or Obsolete? The Fate of the NationState and the Case of Western Europe," Daedalus, Summer 1966 (Vol. 95, Nos. 3-4), pp. 862-916.

- The eta coefficient, a variant of Yule's Q developed by Donald E. Stokes to measure the "nesting" or discriminatory power of items in a scale, was the criterion used to select items from a given factor for construction of Guttman scales. High coefficients of reproducability were obtained for all these scales. For details on how the scales were constructed, see Kerr, "The European Parliament and European Integration," pp. 146-149. A scale for economic integration was not constructed since members and non-members did not differ at all in their attitudes on this issue. It is noteworthy that, once constructed, these scales proved to be almost entirely independent one from the other, a finding that underscores Hoffmann's distinction between high and low politics referred to above.

${ }^{e s}$ In the subsequent analysis, Gaullist deputies-both members and non-members-have been excluded because these delegates do not belong to a cross-national political group and, consequently, are not subject to the group pressures to which it is believed members of the other three groups are exposed. Comparison of the 
category of democratic reform compared to only 29.5 percent among non-members, and 50 percent of the members strongly support a common external policy compared to 38.7 percent of the non-members. Conversely, these members are considerably less opposed to integration along

TABLE 9. LEVEL OF SUPPORT FOR EUROPEAN ISSUE DIMENSIONS BY MEMBERSHIP IN THE EUROPEAN PARLIAMENT AND BY DEGREE OF VOLUNTARISM (GAULLISTS EXCLUDED)

\begin{tabular}{|c|c|c|c|c|c|c|c|}
\hline \multirow[b]{2}{*}{$\begin{array}{l}\text { Issue } \\
\text { Domain }\end{array}$} & \multirow[b]{2}{*}{$\begin{array}{c}\text { Level } \\
\text { of } \\
\text { Support }\end{array}$} & \multicolumn{3}{|c|}{ Non-Members } & \multicolumn{3}{|c|}{ Members } \\
\hline & & $\begin{array}{l}\text { Poten- } \\
\text { tial } \\
\text { Volun- } \\
\text { teers }\end{array}$ & $\begin{array}{l}\text { Non- } \\
\text { Volun- } \\
\text { teers }\end{array}$ & Total & $\begin{array}{c}\text { Self- } \\
\text { Recruits }\end{array}$ & $\begin{array}{c}\text { Party- } \\
\text { Recruits }\end{array}$ & Total \\
\hline \multirow{4}{*}{$\begin{array}{l}\text { Political } \\
\text { Unification }\end{array}$} & Positive & $80.0 \%$ & $48.9 \%$ & $56.4 \%$ & $82.4 \%$ & $57.1 \%$ & $70.0 \%$ \\
\hline & Pro/Con & 20.0 & 36.2 & 32.3 & 17.6 & & 22.5 \\
\hline & Opposed & & 14.9 & 11.3 & & 7.2 & 7.5 \\
\hline & $\begin{array}{c}\text { Total } \\
\mathbf{N}^{\mathrm{b}}=\end{array}$ & $\begin{array}{l}100.0 \% \\
(15)\end{array}$ & $\begin{array}{c}100.0 \% \\
(47)\end{array}$ & $\begin{array}{c}100.0 \% \\
(62)\end{array}$ & $\begin{array}{c}100.0 \% \\
(23)\end{array}$ & $\begin{array}{l}100.0 \% \\
(14)\end{array}$ & $\begin{array}{c}100.0 \% \\
(40)\end{array}$ \\
\hline \multirow{4}{*}{$\begin{array}{l}\text { Democratic } \\
\text { Reform }\end{array}$} & Positive & $53.3 \%$ & $21.7 \%$ & $29.5 \%$ & $52.2 \%$ & $30.8 \%$ & $43.2 \%$ \\
\hline & Pro/Con & 33.3 & 50.0 & 24.6 & 26.1 & 23.1 & 24.3 \\
\hline & Opposed & 13.4 & 28.3 & 45.9 & 21.7 & 46.1 & 32.4 \\
\hline & $\begin{array}{c}\text { Total } \\
\mathrm{N}^{\mathrm{b}}=\end{array}$ & $\begin{array}{c}100.0 \% \\
(15)\end{array}$ & $\begin{array}{c}100.0 \% \\
(46)\end{array}$ & $\begin{array}{c}100.0 \% \\
(61)\end{array}$ & $\begin{array}{c}100.0 \% \\
(23)\end{array}$ & $\begin{array}{c}100.0 \% \\
(13)\end{array}$ & $\begin{array}{c}100.0 \% \\
(37)\end{array}$ \\
\hline \multirow{4}{*}{$\begin{array}{l}\text { Common } \\
\text { Extermal } \\
\text { Relations }\end{array}$} & Positive & $60.0 \%$ & $31.9 \%$ & $38.7 \%$ & $65.2 \%$ & $21.4 \%$ & $50.0 \%$ \\
\hline & Pro/Con & 33.3 & & 32.3 & 34.8 & & \\
\hline & Opposed & 6.7 & 26.2 & 29.0 & & 35.8 & 15.0 \\
\hline & $\begin{array}{l}\text { Total } \\
\mathbf{N}^{b}=\end{array}$ & $\begin{array}{l}100.0 \% \\
(15)\end{array}$ & $\begin{array}{l}100.0 \% \\
(47)\end{array}$ & $\begin{array}{c}100.0 \% \\
(62)\end{array}$ & $\begin{array}{c}100.0 \% \\
(23)\end{array}$ & $\begin{array}{c}100.0 \% \\
(14)\end{array}$ & $\begin{array}{l}100.0 \% \\
(40)\end{array}$ \\
\hline \multirow{4}{*}{$\begin{array}{l}\text { European } \\
\text { Atomic } \\
\text { Strike Force }\end{array}$} & Positive) & & & $32.3 \%$ & & & $22.5 \%$ \\
\hline & Pro/Con $\}$ & & & 23.2 & $11.4 \%$ & $10.1 \%$ & 32.5 \\
\hline & Opposed & 42.9 & 75.0 & 43.5 & 28.6 & 83.3 & 45.0 \\
\hline & $\begin{array}{l}\text { Total } \\
N^{c}=\end{array}$ & $\begin{array}{c}100.0 \% \\
(7)\end{array}$ & $\begin{array}{l}100.0 \% \\
(12)\end{array}$ & $\begin{array}{c}100.0 \% \\
(60)\end{array}$ & $\begin{array}{c}100.0 \% \\
(7)\end{array}$ & $\begin{array}{c}100.0 \% \\
(6)\end{array}$ & $\begin{array}{l}100.0 \% \\
(40)\end{array}$ \\
\hline
\end{tabular}

- For details on how these codes were constructed, see Kerr, "The European Parliament and European Integration," p. 151.

- The total $\mathrm{N}$ for members is slightly larger than the $n$ 's for self-recruits and party-recruits taken together, since the type of recruitment was not ascertained for three of the members.

- The comparison between members and non-members is based on the total $\mathrm{N}$ of non-Gaullists interviewed, whereas the n's for type of recruitment include only German Christian Democrats. See footnote no. 64 below.

attitudes of Gaullist members and non-members revealed that though few differences existed between them, the UNR delegates sent to Strasbroug tended to be more hostile on these four issue dimensions than their national colleagues. It looked as though the Gaullist parliamentary group in the National Assembly made a special effort to appoint hard-liners on these issues to the European Parliament. See ibid, pp. 64-65. 
these three issue dimensions than are their national colleagues. Only on the issue of creating a European atomic strike force are the members, on the whole, less positive in their support than non-members, but these differences are not statistically significant. For the moment it suffices to say that these strong differences in three of four issue areas are inital grounds for inferring that attitudes toward political integration change as a result of experience in the assembly.

Yet once the effects of self-selection are controlled, these differences in overall level of support for these several issues virtually disappear. Table 9 clearly shows that the support given to further integration within these several domains is almost the same, on the one hand, among non-members who are ready to volunteer their nomination to the parliament and self-recruited members and, on the other hand, among those non-members not interested in going to Strasbourg and party-recruited members. What is striking is that the pattern of these results is consistently the same across all four issue areas. ${ }^{64}$ This finding is persuasive evidence for the hypothesis that it is the strength of the self-recruited members' initial attitudes that prompted them to offer their names in nomination in the first place. Since relatively more members are self-recruits than party-recruits, it is not surprising that the average levels of support that the members, as a whole, give to these issues is higher than the average level of the non-members, among whom a disproportionately large number consists of non-volunteers. Moreover, when the degree of the members' commitment to these issues is tabulated against length of membership in the parliament, only a weak, statistically insignificant developmental increase can be detected. Taken together, these two findings considerably reduce the confidence one can place in the hypothesis that participation in the parliament changes the affective component of the members' attitudes. From this evidence, one cannot fully share Lindberg's conviction that one of the principal functions of the European Parliament is to bring about changes in the members' attitudes, or Feld's argument that "the involvement of Communist delegates [nominated by the French and Italian Communist parties] might engender more positive attitudes toward the development of the Common Market as envisaged in the Community treaties."

\footnotetext{
at On the issue of creating an European atomic strike force, table 9 reports these differences only for the German Christian Democrats, since this was the only group of members and non-members that showed any differences in their attitudes toward this issue. See ibid, pp. 160-161.

${ }^{\circ}$ See footnote no. 21 above, and Werner Feld, "The French and Italian Com. munists and the Common Market: The Request for Representation in the Community," Journal of Common Market Studies, March 1968 (Vol. VI, No. 3), p. 264 .
} 
strong support for European integration among non-Gaullist members of the European Parliament recorded by many observers frequently results from their having been drawn to participate in its deliberations by force of their original convictions. This conclusion is very much in line with Haas's observations of the ECSC Common Assembly and with the findings that Bonham drew from his study of Scandinavian parliamentarians sent to the Consultative Assembly of the Council of Europe.

In a sequel to this null finding about the effects of membership on the participants' attitudes, it was discovered that national party affiliation is a powerful predictor of the respondents' attitudes toward all five issue dimensions. Since at the outset of this study it was expected that these attitudes would show a strong developmental increase, partial correlation coefficients were calculated for the relationship between these attitude scales and four independent variables-party affiliation, age, length of membership, and degree of voluntarism-in order to assess the relative magnitude of the effects attributable to participation. ${ }^{66}$ What emerged instead is that party affiliation took on a wholly unexpected importance in the explanation of the variance in these scales, as table 10 shows. The total amount of variance accounted for by only

TABLE 10. PARTIAL ETA' COEFFICIENTS FOR THE RELATIONSHIPS BETWEEN FOUR INDEPENDENT VARIABLES AND THE FIVE ATTITUDINAL DIMENSIONS

\begin{tabular}{|c|c|c|c|c|c|}
\hline $\begin{array}{l}\text { Independent } \\
\text { Variable }\end{array}$ & $\begin{array}{l}\text { Political } \\
\text { Unifi- } \\
\text { cation }\end{array}$ & $\begin{array}{l}\text { Demo- } \\
\text { cratic } \\
\text { Reform }\end{array}$ & $\begin{array}{c}\text { Common } \\
\text { External } \\
\text { Relations }\end{array}$ & $\begin{array}{c}\text { European } \\
\text { Atomic } \\
\text { Strike } \\
\text { Force }\end{array}$ & $\begin{array}{c}\text { Type of } \\
\text { Econ- } \\
\text { omy }\end{array}$ \\
\hline \multicolumn{6}{|l|}{ Party } \\
\hline Affiliation & .28 & .20 & .46 & .45 & .43 \\
\hline Age & .01 & .15 & .02 & .04 & .03 \\
\hline Length of & 02 & 04 & & 01 & \\
\hline $\begin{array}{l}\text { Membership } \\
\text { Recruitment }\end{array}$ & .02 & .04 & $\begin{array}{r}.02 \\
08\end{array}$ & .01 & $\begin{array}{r}.01 \\
0 ?\end{array}$ \\
\hline Multiple $\mathbf{R}^{\prime}$ & .23 & .23 & .40 & $\begin{array}{l}.03 \\
.43\end{array}$ & $\begin{array}{l}.02 \\
.40\end{array}$ \\
\hline
\end{tabular}

* The method of analysis used was multiple classification analysis (MCA), which is a means of estimating partial correlation coefficients for nominal level data. The measure of association is called eta (not to be confused with Stoke's eta referred to above). See Fred M. Andrews, James N. Morgan, and John A. Sonquist, Multiple Classification Analysis (Ann Arbor: Institute for Social Research, 1967). The categories used for the independent variables in this analysis were as follows: (1) national party affiliation by the seven national parties represented in the French and German samples; (2) age by the brackets of (a) 40 years old or less, (b) 41 to 49 , (c) 50 to 59 , (d) 60 to 69 , and (e) 70 years or older; (3) length of membership by (a) non-member (zero years), (b) less than one to two years, (c) three to six years, and (d) seven years or longer; and, (4) recruitment by the four categories of potential volunteers, non-volunteers, self-recruits, and party-recruits. 
these four variables is substantial, ranging from .23 for the dimensions of political unification and democratic reform to about .40 for those of common external relations, the European atomic strike force, and type of economy. Secondly, in all instances, the partial effect of party affiliation invariably shows the highest squared eta coefficients in comparison with the extremely low (almost nil) coefficients for the other three variables. Only for the relationship of age to democratic reform and of recruitment to common external relations do the other partial coefficients rise above the level of .05 . What stands out is the importance of party affiliation as a predictor of the respondents' positions on these five attitudinal dimensions. The amount of variance accounted for by party affiliation when the other three variables are held constant ranges from a sizeable .20 to a very strong .46 .

Along with the potency of party affiliation go notably weak predictive values for length of membership. Its unimportance as a predictor is what would be expected from the preceding analysis. Recruitment is an equally weak predictor, but recall that recruitment was used primarily to interpret the differences observed between members and non-members; it was not a necessary condition of its interpretative value that it also account for the overall variance in the dependent attitudinal variables. Age was included as a variable because of the expectation that it should predict variations in attitudes along these dimensions. ${ }^{67}$ Obviously, it does not, once other variables are held constant.

These findings suggest that the attitudes of the members still have deep roots in the members' affiliations to their national parties. Evidently the members' present beliefs about these questions are strongly anchored in the national setting. This may explain, in part, why the effects on the affective component are noticeably weak: the roles that the members assume in performing their duties within the parliament apparently are not sufficiently well defined, nor strong enough, to diminish the importance of these national ties. It may be hypothesized that to the extent that the members feel strong attachments to the positions taken by their national parties, the effect of membership in one of the three cross-national party groups in the parliament is weakened to an equal degree. Since the political groups dispose of neither the means to enforce group discipline nor rewards for advancement in a political career, the strength of association between the members' stands on European issues and national party affiliations probably indicates that the rewards for adoption of a given stand are perceived by the members as emanating from the national setting. It is in the national party groups that careers are made or broken.

\footnotetext{
or See Inglehart, The American Political Science Review, Vol. LXI, No. 1, passim.
} 
This reflection does not necessarily imply that national party considerations play a major role in the parliament's deliberations; the members' attitudes simply show the marks of these national affiliations. This is a remarkable testimony to the party relatedness of legislators' attitudes toward European integration. It is also this characteristic of their attitudes that may well facilitate consensus formation within the political groups: the more party-related are the attitudes of the members, the easier it is for a member to align himself with parties of like tendency grouped together under a common label within the parliament.

\section{CONCLUSION}

At the outset of this inquiry, several institutional factors were identified as possible contributors to changes in the members' attitudes toward European integration. The presence of a strong parliamentary tradition, the exposure to new information, the prevalence of nonnational roles, and the incipient formation of cross-national party groupings were seen as forces facilitating these changes. Yet the findings of this study do not support these hypotheses in their entirety. As in studies of the effects of international contact, it was found that the experience of participating in the work of the European Parliament most likely has effects on the cognitive, but not the affective, component of the members' attitudes. The members rely much more extensively upon international sources of information, make finer distinctions among the issues, and perceive European questions as more central to their concerns than do non-members not interested in nomination to the parliament. That the members do not differ along these cognitive dimensions by type of recruitment, and that the degree of usage of international sources, cognitive differentiation, and centrality of the issues increases with length of membership, are support for this conclusion. On the other hand, differences in the degree of support for European integration along five issue dimensions appear largely attributable to differential patterns of recruitment. Since self-recruited members to the European Parliament and potential volunteers in the national parliaments both support these issues at an equally higher level than partyrecruits at Strasbourg and non-volunteers in the national capitals, the slightly stronger support members give, on the whole, to these issues appears to be the result of the substantial percentage of self-recruited members who are drawn to participate in the parliament because of favorable attitudes they held prior to their nomination. Furthermore, the degree of support for these issues among the members does not show a statistically significant increase with length of membership.

The effects of participation thus appear to be limited to cognitive changes. It is possible, of course, that effects on the affective compo- 
nent of the members' attitudes do exist but were not detected by the methods used in this survey. This is an unavoidable risk one runs in inferring changes from comparisons made in a cross-sectional field survey in which, unlike in a laboratory setting, measures of change in the dependent attitudinal variables are not taken over time, nor are the independent variables susceptible to manipulation by the researcher ${ }^{68}$ However, since it is usually harder to detect cognitive effects than it is to uncover affective ones, ${ }^{69}$ the evidence of consistent effects across the cognitive, but not the affective, dimensions of the attitudes analyzed in this survey provides stronger assurance that the findings of this research reflect the true state of affairs.

That participation in the European Parliament may produce only cognitive effects is not a trivial finding. From the members' own testimony, the experience is perceived as enhancing their expertise in European matters and broadening their views on the issues debated. It is not so much that their cognitions are altered as that they expand their general store of knowledge, their judgments gain in nuance, and European issues become more central to their concerns. Not only does the experience thus appear to increase their own personal expertise, but it also enhances their stature as experts in the eyes of their national colleagues. That the members are named as European experts by their national compatriots in numbers disproportionate to their strength in the national parliaments reflects the importance of this experience to the training of qualified European spokesmen in the national settings. Although the members apparently do not return to the national capitals more committed, or less opposed, to European integration, they do bring back the benefits of a broader outlook and more knowledge about these questions. In effect, the members appear to serve as an important communications channel from the international to the national setting.

Apart from these explicit findings, it is worthwhile to speculate about other indirect effects that participation in the parliament's activities may produce. From the members' point of view, one of the major advantages of membership is the opportunity to become acquainted with their counterparts from the other member states. Though many of the members expressed frustration at the inability of the parliament to exercise any effective control over the community's decisions, most feel partially compensated by the personal ties and friendships they form with other legislators from throughout the community. It is likely that this interpersonal contact tends to reduce the tendency to stereo-

For a comparison of field and laboratory methods, see Carl I Hovland, "Reconciling Conflicting Results Derived from Experimental and Survey Studies of Attitude Change," American Psychologist, 1959 (Vol. XIV, No. 1), pp. 8-17.

* Personal communication from Professor Daniel Katz. 
type and enhances the development of reciprocal identifications. In the interviews with the members, there was an unmistakable undertone of an attitude that might best be characterized as "we're all in the same boat." It is as if the very impotence of the parliament led the members to develop a strong sense of common identification as "European," not French or German, legislators. As a result, along with the formation of personal ties may go a heightened degree of mutual responsiveness. ${ }^{70}$

The presence of three distinct, cross-national party groupings may also heighten the members' sense of common loyalty. Instead of viewing one another as nationals, the members are likely to identify with each other as adherents of similar political tendencies. The association of members along party rather than national lines of opposition probably makes the sense of common allegiance stronger. The members may well develop a set of reciprocal expectations that defines their roles in the parliament not as those of national partisans, but rather as members of a transnational political movement. ${ }^{71}$ In effect, the opposition of distinct political groupings may help to foster loyalties that transcend national identifications. This line of speculation requires further examination, however, in light of the finding that participation in the parliament apparently does not lead to changes in the affective component of the members' attitudes. If the parliament were viewed as a collection of extra-national roles into which national legislators are inducted, it would probably follow that the members' attitudes would be altered in the direction of a stronger commitment to regional cooperation. ${ }^{22}$ It was previously hypothesized that the prevalence of non-national roles in the parliament, particularly those associated with membership in the political groups, may give rise to pressures which induce the members to revise their attitudes in the direction of group norms. This change does not appear to occur, however. Although the evidence presented is not conclusive, several explanations may be offered.

In the first place, no positive or negative sanctions are attached to the roles of group member or spokesman. Unlike national parlia-

${ }^{70}$ See Bruce M. Russett, "International Communication and Legislative Behavior: The Senate and the House of Commons," Journal of Conflict Resolution, 1962 (Vol. VI, No. 2), pp. 291-307.

${ }^{71}$ For a general theoretical exploration of how interpersonal contact at the international level may affect an individual's role definition as a national, see Stewart E. Perry, "Notes on the Role of the National: A Social-Psychological Concept for the Study of International Relations," Journal of Conflict Resolution, December 1957 (Vol. I, No. 4), pp. 346-363.

${ }^{72}$ In a different context, Lieberman has demonstrated the link between role assumption and attitude change. See Seymour Lieberman, "The Effects of Changes in Roles on the Attitudes of Role Occupants," Human Relations, 1956 (Vol. IX, No. 4), pp. 385-402. 
mentary groups, the political groups in the European Parliament possess no means to enforce group discipline and, for that matter, are loath to censure members for the expression of individual opinions which run contrary to group sentiment. Though membership in one of the three transnational party groupings may foster the development of group attachments that are extranational in content, it does not carry with it sharply defined roles with which specific attitudes are associated. Secondly, the members' playing of these roles is episodic; being a European parliamentarian is not a full-time occupation. The political rewards for adoption of a given stance toward European questions are clearly perceived by the members as emanating from the national settings where their political careers are made or broken. This may explain, in part, why national party affiliation is the strongest predictor of the members' attitudes; the non-national roles assumed by members in the parliament do not possess sufficient strength to diminish the importance of their ties to the constituent national parliamentary groups.

For the most part, the experience of participating in the legislative work of the European Parliament is thus of a highly personal nature. It is seen as an opportunity to broaden personal horizons and to become intimately acquainted with foreign colleagues as well as with the issues. What an individual delegate carries away from his experience is primarily a function of exposure, not of situational or role constraints. Role expectations are not sufficiently well defined, or backed by strong enough rewards or sanctions, to induce attitude changes. Yet the stimuli associated with intensive exposure to new information about European integration apparently have distinguishable, cognitive effects, probably attributable to the character of personal experiences and contacts.

These conclusions are identical to those that Haas drew from his observations of the ECSC Common Assembly in 1957.73 In the period between 1958 and 1967, the European Parliament-the Common Assembly's successor-has not undergone any fundamental change in its sphere of competence, in the character of the recruitment of its members, or in the structure of its activities, which would increase its contribution to European integration. The more vocal, pro-European deputies in the national parliaments are still recruited in disproportionate numbers to the parliament, the experience still does not appear to alter the members' attitudes, and the most meaningful function of the parliament is to enhance the members' expertise and thus to open up a communications channel between the national and European levels.

The identical character of these findings suggests a similar conclusion: the European Parliament will assume a more important role

${ }^{7}$ Haas, The Uniting of Europe, pp. 390-440. 
in the European process only when its present powers are substantially increased. ${ }^{74}$ At the moment when parliamentary control becomes more tangible, several consequences may follow. First, it is likely that the parliament will recruit from a broader base and stimulate a much greater interest among national legislators. Secondly, the political groups in the parliament may become more disciplined and place more pressure on their adherents to conform to group positions. Thirdly, along with this increase in pressure, the visibility of the stakes may serve as an inducement to make the members revise their opinions and attitudes. Finally, the members may come to exercise proportionately greater influence on the decisions taken by the national parliamentary groups in this policy domain, since the effective control over the direction of certain aspects of European policy would have fallen into their hands at the expense of the prerogatives of national parliaments.

These are only suppositions that future events may or may not bear out. In the interim, it appears that the role of the parliament is limited to the effects that participation in its activities has on the members' cognitions and expertise. The one good omen for the future is the high percentage of strongly committed Europeans who are drawn to participate in the work of this international assembly. Once the powers of the European Parliament are increased, it is likely that these Europeans will have a decisive voice in the construction of a viable parliamentary institution. So long as the parliament can count on this reservoir of strong support, its future seems assured.

\footnotetext{
${ }^{74}$ Observers of the parliament are at one in this conclusion. See, inter alia, Murray Forsyth, The Parliament of the European Communities, pp. 94-97; Schwarz, "Power, Persuasion and the Influence of the European Parliament," pp. 248-257; Lindberg, in Frank (ed.), Lawyers in a Changing World, pp. 101-128; and, Anne-Marie Houdbine and Jean-Raymond Verges, Le Parlement Européen dans la Construction de l'Europe des Six, (Paris: Presses Universitaires de France, 1968).
} 